\title{
Composition of Precursor B-Cell Compartment in Bone Marrow from Patients with X-Linked Agammaglobulinemia Compared with Healthy Children
}

\author{
JEROEN G. NOORDZIJ, SANDRA DE BRUIN-VERSTEEG, W. MARIEKE COMANS-BITTER, \\ NICO G. HARTWIG, RUDOLF W. HENDRIKS, RONALD DE GROOT, AND \\ JACQUES J.M. VAN DONGEN
}

Department of Immunology, Erasmus University Rotterdam/University Hospital Rotterdam-Dijkzigt, 3000 DR, Rotterdam [J.G.N., S.d.B.-V., W.M.C.-B., R.W.H., J.J.M.v.D.], and Department of Pediatrics, Division of Infectious Diseases and Immunology, Sophia Children's Hospital/University Hospital Rotterdam, 3000 CB, Rotterdam, The Netherlands [S.d.B.-V., N.G.H., R.d.G.]

\begin{abstract}
ABST
X-linked agammaglobulinemia (XLA) is characterized by a
severe B-cell deficiency, resulting from a differentiation arrest in
the bone marrow (BM). Because XLA is clinically and immu-
nologically heterogeneous, we investigated whether the B-cell
differentiation arrest in BM of XLA patients is heterogeneous as
well. First, we analyzed BM samples from 19 healthy children by
flow cytometry. This resulted in a normal B-cell differentiation
model with eight consecutive stages. Subsequently, we analyzed
BM samples from nine XLA patients. Eight patients had amino
acid substitutions in the Bruton's tyrosine kinase (BTK) domain
or premature stop codons, resulting in the absence of functional
BTK proteins. In seven of these eight patients a major differen-
tiation arrest was observed at the transition between cytoplasmic
Ig ${ }^{-}$pre-B-I cells and cytoplasmic Ig $\mu^{+}$pre-B-II cells, consis-
tent with a role for BTK in pre-B-cell receptor signaling. How-
ever, one patient exhibited a very early arrest at the transition
between pro-B cells and pre-B-I cells, which could not be
explained by a different nature of the BTK mutation. We con-
clude that the absence of functional BTK proteins generally leads
to an almost complete arrest of B-cell development at the pre-B-I
to pre-B-II transition. The ninth XLA patient had a splice site
mutation associated with the presence of low levels of wild-type
BTK mRNA. His BM showed an almost normal composition of
\end{abstract}
the precursor B-cell compartment, suggesting that low levels of BTK can rescue the pre-B-cell receptor signaling defect, but do not lead to sufficient numbers of mature B lymphocytes in the peripheral blood. (Pediatr Res 51: 159-168, 2002)

\section{Abbreviations}

XLA, X-linked agammaglobulinemia

PB, peripheral blood

BTK, Bruton's tyrosine kinase

aa, amino acids

BM, bone marrow

Cy, cytoplasmic

Sm, surface membrane

wt, wild type

LWBM, lysed whole BM

MC, mononuclear cell

PE/Cy5, phycoerythrin-cyanine5

TdT, terminal deoxynucleotidyl transferase

NK, natural killer

RT, reverse transcriptase

LR, long range

BCR, B-cell receptor
XLA is a primary immunodeficiency, which affects approximately 1 in 100,000 boys and is characterized by agamma- or hypogammaglobulinemia and strongly reduced numbers of $B$ lymphocytes in PB (1). The clinical picture of XLA generally develops during the first year of life, after maternal antibodies have disappeared from the serum, with frequent infections of

Received November 17, 2000; accepted March 15, 2001.

Correspondence and reprint requests: J.J.M. van Dongen, M.D., Ph.D., Department of Immunology, Erasmus University Rotterdam, P.O. Box 1738, 3000 DR, Rotterdam, The Netherlands; e-mail: vandongen@immu.fgg.eur.nl different organ systems, particularly upper and lower respiratory tract and gastrointestinal infections, but also bacterial skin infections, meningitis, septicemia, or osteomyelitis $(1,2)$.

XLA is caused by mutations in the gene encoding BTK, located on Xq21.3 $(3,4)$. BTK is a cytoplasmic protein of 659 aa, composed of five different domains, the pleckstrin homology, Tec homology, Src homology 3, Src homology 2, and kinase domain (1). So far, 341 unique mutations have been reported, which are scattered throughout the gene (5). No correlation has been described between the type and position of 
the mutations and phenotypic variables, such as age or serum Ig levels at diagnosis or severity of infections $(2,6)$. XLA is a heterogeneous disease $(7,8)$, which could be the result of differences in mutations in the $B T K$ gene, in combination with other genetic or environmental factors, infections, or age of the patients.

Early studies have shown that in XLA a B-cell differentiation arrest occurs in BM (9-11). However, controversy exists regarding the stage in B-cell development that is primarily affected by mutations in the $B T K$ gene. Differentiation arrests have been described between $\operatorname{CyIg} \mu^{+}$precursor B cells and $\mathrm{SmIgM}^{+}$immature B cells as well as at the transition of $\mathrm{CyIg} \mu^{-}$into $\mathrm{CyIg} \mu^{+}$precursor B cells $(10,11)$. These findings could reflect heterogeneity in the stages at which B-cell development is arrested, in parallel with the clinical and immunologic heterogeneity of XLA (12-14). In a recent study, MAb against the surrogate light chains were used to characterize the differentiation arrest (15). It was shown that the major blockade in XLA patients was located at the transition from large to small CyIg $\mu^{\text {low }}$-surrogate light chain ${ }^{\text {bright }}$ pre-B cells (15). However, the authors did not discuss the severity of the blockade. The severity of this arrest might be variable, because XLA patients differ in the absolute numbers of mature B lymphocytes in their $\mathrm{PB}$, which suggests that variable degrees of leakiness exist (16). The residual B cells can proliferate, undergo IgH isotype switching, and differentiate into specific antibody-producing cells (17). We hypothesized that an accurate characterization of the $\mathrm{B}$-cell differentiation arrest in $\mathrm{BM}$ of XLA patients would help to explain the level of immunologic variation and provide information on the function of BTK in early B-cell development in man.

Several recent flow cytometric studies have shown that in human BM, five to six B-cell differentiation stages can be distinguished (18-22). According to Ghia et al. (19, 21), pro-B, pre-B-I, large pre-B-II, small pre-B-II, immature B, and mature $\mathrm{B}$ cells can be recognized in man on the basis of Ig rearrangement and cytoplasmic or surface Ig expression. BTK functions as a signal-transducing element downstream of the BCR, thereby directing B-cell development (23).

To unravel the precise B-cell differentiation arrest in XLA patients and to obtain information on the degree of leakiness, we performed detailed flow cytometric studies of nine BM samples from XLA patients together with $19 \mathrm{BM}$ samples from healthy children younger than $16 \mathrm{y}$ of age as controls.

\section{METHODS}

Cell samples. We received BM samples from 19 healthy children (youngest age, 1 y 7 mo; oldest 16 y 1 mo; median, 8 y 2 mo; 10 boys, 9 girls), who were donors for BM transplantation of their siblings (Department of Pediatrics, Leiden University Medical Center; Drs. P.M. Hoogerbrugge and J.M.J.J. Vossen). These control BM samples were used for detailed flow cytometric studies, via the LWBM method (24) as well as after Ficoll-Paque density centrifugation (density, $1.077 \mathrm{~g} / \mathrm{mL}$; Pharmacia, Uppsala, Sweden).

We received $\mathrm{BM}$ and $\mathrm{PB}$ samples from nine XLA patients during the last $15 \mathrm{y}$. BM samples from four recent XLA patients were used for flow cytometric analysis according to the LWBM method. The BM samples from the other five XLA patients were subjected to Ficoll density centrifugation. The recovered $\mathrm{MC}$ were frozen and stored in liquid nitrogen and thawed later for flow cytometric immunophenotyping studies.

Granulocytes and $\mathrm{MC}$ were isolated from $\mathrm{PB}$ by Ficoll density centrifugation and used for DNA or RNA extraction.

All cell samples were obtained according to the informed consent guidelines of the Medical Ethics Committees of the Leiden University Medical Center and the University Hospital Rotterdam.

Comparison of cell samples. In four healthy children, we compared the results of flow cytometric analysis of fresh BM via the LWBM method with the results obtained from thawed BMMC. Furthermore, in five other healthy children, we compared the results of flow cytometric analysis of fresh BM via the LWBM method with the results obtained from freshly isolated BMMC. All flow cytometric data concerning the precursor B-cell compartment were analyzed independently by two experienced technicians and did not show significant changes before and after Ficoll density centrifugation as well as before and after freezing and thawing of $\mathrm{MC}$, implying that no major selective loss of particular precursor B-cell subsets occurred. Moreover, using BMMC from our cell bank (storage in liquid nitrogen) was the only way we could obtain BM samples from enough XLA patients to perform this study.

Flow cytometric analysis of BM from healthy children and $\boldsymbol{X L A}$ patients. BM samples were diluted with $\mathrm{PBS}(\mathrm{pH} 7.8)$ to a concentration of $15 \times 10^{6}$ cells $/ \mathrm{mL}$. Twenty-five microliter aliquots of whole BM or BMMC were incubated for $10 \mathrm{~min}$ at

Table 1. Triple labelings for analysis of B-cell differentiation

\begin{tabular}{|c|c|c|c|}
\hline & $\begin{array}{l}\text { FITC- } \\
\text { conjugates }\end{array}$ & PE-conjugates & $\begin{array}{l}\text { PE-Cy5- } \\
\text { conjugates }\end{array}$ \\
\hline \multicolumn{4}{|c|}{ MAb directed against membrane antigens } \\
\hline 1 & $\begin{array}{l}\mathrm{CD} 34 \\
(\mathrm{HPCA}-2)^{*}\end{array}$ & CD22 (Leu-14)* & CD19 (HIB19)§ \\
\hline 2 & $\begin{array}{l}\text { CD34 } \\
\text { (HPCA-2) }\end{array}$ & CD10 (J5) & CD19 (HIB19) \\
\hline 3 & $\begin{array}{l}\text { CD34 } \\
(\text { HPCA-2) }\end{array}$ & CD38 (Leu-17)* & CD19 (HIB19) \\
\hline 4 & $\begin{array}{l}\mathrm{CD} 34 \\
(\mathrm{HPCA}-2)\end{array}$ & CD20 (Leu-16)* & CD19 (HIB19) \\
\hline 5 & $\begin{array}{l}\text { CD10 } \\
(\text { (J5) } \dagger\end{array}$ & CD20 (Leu-16) & CD19 (HIB19) \\
\hline 6 & SmIgM $\|$ & CD10 (J5) & CD19 (HIB19) \\
\hline 7 & SmIgD\| & SmIgM (MB-11) & CD19 (HIB19) \\
\hline \multicolumn{4}{|c|}{$\begin{array}{l}\text { MAb directed against membrane antigens and TdT via FACS Lysing } \\
\text { Solution }\end{array}$} \\
\hline 8 & TdT (hTdT-6) & CD22 (Leu-14) & CD19 (HIB19) \\
\hline 9 & TdT (hTdT-6) & CD34 (HPCA-2) & CD19 (HIB19) \\
\hline 10 & TdT (hTdT-6) & CD10 (J5) & CD19 (HIB19) \\
\hline \multicolumn{4}{|c|}{$\mathrm{MAb}$ directed against membrane antigens and $\mathrm{CyIg} \mu$ via IntraPrep } \\
\hline 11 & $\mathrm{CyIg} \mu \|$ & CD34 (HPCA-2) & CD19 (HIB19) \\
\hline 12 & $\operatorname{CyIg} \mu$ & CD10 (J5) & CD19 (HIB19) \\
\hline 13 & $\operatorname{CyIg} \mu$ & CD38 (Leu-17) & CD19 (HIB19) \\
\hline 14 & CyIg $\mu$ & SmIgM (MB-11) & CD19 (HIB19) \\
\hline
\end{tabular}

MAb were derived from * Becton Dickinson (San Jose, CA, U.S.A.); $\dagger$ Beckman Coulter (Brea, CA, U.S.A.); \$Sigma Aldrich (St. Louis, MO, U.S.A.); § Serotec (Raleigh, NC, U.S.A.); $\|$ Kallestad/Sanofi-Synthelabo (Paris, France); ๆ Supertechs (Bethesda, MD, U.S.A.). 
Table 2. Composition of the BM lymphogate

\begin{tabular}{|c|c|c|c|c|c|c|}
\hline & \multicolumn{2}{|c|}{$\mathrm{CD} 22^{+} \mathrm{B}$ cells $(\%)$} & $\begin{array}{c}\mathrm{CD}^{+} \mathrm{T} \\
\text { lymphocytes } \\
(\%)\end{array}$ & $\begin{array}{l}\mathrm{CD} 16^{+} / \mathrm{CD} 56^{+} \\
\text {NK cells }(\%)\end{array}$ & $\begin{array}{c}\mathrm{CD} 13^{+} / \mathrm{CD} 33^{+} \\
\text {myeloid cells } \\
(\%)\end{array}$ & 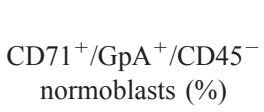 \\
\hline Healthy children $<5$ y $(n=6)$ & $36 \pm 7$ & $12 \pm 9$ & $22 \pm 13$ & $3 \pm 1$ & $6 \pm 3$ & $25 \pm 16$ \\
\hline Healthy children $10-16$ y $(n=6)$ & $26 \pm 11$ & $7 \pm 4$ & $25 \pm 5$ & $3 \pm 1$ & $5 \pm 2$ & $35 \pm 13$ \\
\hline XLA1 (LWBM) & 15 & 0.2 & 55 & 6 & 5 & 20 \\
\hline XLA2 (thawed BMMC) & 8 & 0.2 & 39 & 15 & 11 & 26 \\
\hline XLA5 (thawed BMMC) & 39 & 0.2 & 23 & 12 & 5 & 17 \\
\hline XLA6 (LWBM) & 12 & 0.03 & 68 & 5 & 7 & 15 \\
\hline XLA7 (thawed BMMC) & 20 & 0.03 & 52 & 16 & 2 & 6 \\
\hline XLA8 (LWBM) & 9 & 0.1 & 56 & 6 & 3 & 25 \\
\hline XLA9 (LWBM) & 26 & 2.2 & 29 & 7 & 5 & 34 \\
\hline
\end{tabular}

* Percentage of precursor B cells was calculated by subtracting the percentage of mature B cells from the total percentage of CD22 ${ }^{+}$B cells.

$\dagger$ Percentage of mature B cells was based on the $\mathrm{CD}_{10} / \mathrm{SmIgM}^{+}$or $\mathrm{SmIgM}^{+} / \mathrm{SmIgD}^{+}$populations (labelings 6 and 7 from Table 1).

room temperature with combinations of optimally titrated MAb: $25 \mu \mathrm{L}$ FITC-conjugated MAb, or $25 \mu \mathrm{L}$ phycoerythrinconjugated MAb, or $25 \mu \mathrm{L}$ PE/Cy5-conjugated Mab, or combinations of preceding MAbs were used to detect membranebound antigens. After incubation, the cells were washed and further processed depending on the type of triple labeling. The 14 applied triple labelings are summarized in Table 1.

Triple labelings for three membrane-bound antigens (labelings 1-7 in Table 1) were directly analyzed by flow cytometry using FACScan (Becton Dickinson, San Jose, CA, U.S.A.) in case of BMMC, whereas whole BM samples were first subjected to lysis of the erythrocytes using FACS Lysing Solution (Becton Dickinson).

Permeabilization of the BM cells using FACS Lysing Solution (Becton Dickinson) was performed before intranuclear staining of TdT both on whole BM samples and BMMC (labelings $8-10$ in Table 1) $(24,25)$.

Intracellular staining of $\operatorname{Ig} \mu(\operatorname{Cy} \operatorname{Ig} \mu)$ was performed after permeabilization of the BM cells using IntraPrep Permeabilization Reagent (Immunotech, Marseille, France) both on whole BM samples and BMMC (labelings 11-14 in Table 1) $(24,25)$.

$D N A$ and $R N A$ extraction and $R T$ reaction. DNA was extracted from PBMC or granulocytes using the QIAamp Blood kit (Qiagen, Chatsworth, CA, U.S.A.) (26). Total RNA was isolated from $\mathrm{PB}$ granulocytes according to the method of Chomczynski and Sacchi (27) using RNAzol B (Tel-Test, Friendswood, TX, U.S.A.). cDNA was prepared from $1 \mu \mathrm{g}$ of mRNA as described before, using oligo(dT) and avian myeloblastosis virus (AMV) RT (Promega, Madison, WI, U.S.A.) (28).

PCR amplification of (c)DNA. PCR was performed as described previously (29). Exons 1-13 and exon 19 of the BTK gene were amplified separately, whereas exons $14-18$ were amplified in one LR-PCR reaction. In each $100 \mu \mathrm{L}$ of PCR reaction, $0.1 \mu \mathrm{g}$ of (c)DNA, 20 pmol of 5' and 3' oligonucleotides, and $1 \mathrm{U}$ of AmpliTaq gold polymerase (Applied Biosystems, Foster City, CA, U.S.A.) were used. PCR conditions were $2-10 \mathrm{~min}$ at $94^{\circ} \mathrm{C}$, followed by $60 \mathrm{~s}$ at $92^{\circ} \mathrm{C}, 60 \mathrm{~s}$ at $57-60^{\circ} \mathrm{C}$, and $2 \mathrm{~min}$ at $72^{\circ} \mathrm{C}$ for 40 cycles, followed by a final extension step $\left(7 \mathrm{~min}\right.$ at $\left.72^{\circ} \mathrm{C}\right)$.
In each $100 \mu \mathrm{L}$ of LR-PCR reaction, $0.1 \mu \mathrm{g}$ of DNA sample, 5.25 U of Expand enzyme mix (Boehringer Mannheim, Mannheim, Germany), and 30 pmol of $5^{\prime}$ and $3^{\prime}$ oligonucleotides were used. LR-PCR conditions were $2 \mathrm{~min}$ at $94^{\circ} \mathrm{C}$, followed by $15 \mathrm{~s}$ at $94^{\circ} \mathrm{C}, 30 \mathrm{~s}$ at $57^{\circ} \mathrm{C}$, and $4 \mathrm{~min}$ at $68^{\circ} \mathrm{C}$ for 40 cycles using $10 \mathrm{~s}$ autoextension from cycle 21 onward. After the last cycle an additional step of $10 \mathrm{~min}$ at $72^{\circ} \mathrm{C}$ was performed for final extension.

The sequences of the oligonucleotides used for PCR amplification of BTK were based on Oeltjen et al. (30) (Genbank accession number U78027) and were designed with the OLIGO 6 program (Dr. W. Rychlik, Molecular Biology Insights, Cascade, CO, U.S.A.) (31). Primer sequence data will be made available on request to interested readers.

Fluorescent sequencing reaction and analysis. LR-PCR products of BTK exons 14-18 were first purified with the QIAquick PCR purification kit (Qiagen), whereas short PCR products (exons 1-13 and 19) were used directly for sequencing with $5 \mu \mathrm{L}$ of dRhodamine dye terminator mix (Applied Biosystems), using 3.3 pmol of sequencing primers. The sequencing primers were positioned in the BTK introns just upstream and downstream of the exon-intron borders, so that
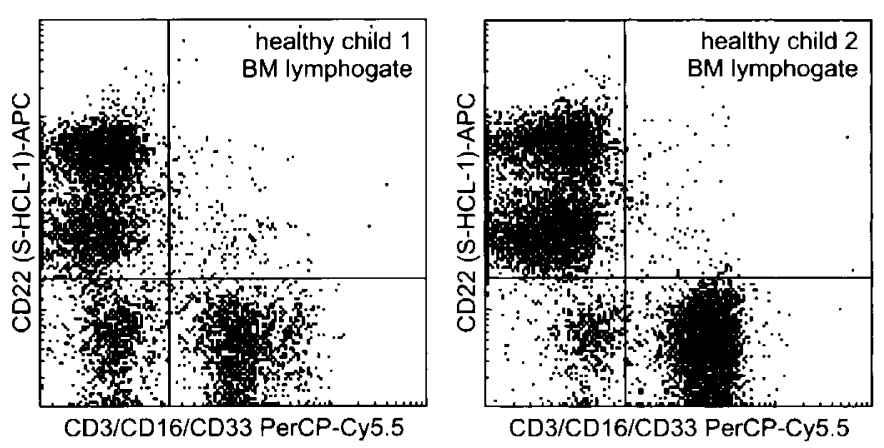

Figure 1. Flow cytometric analysis of BM samples from two healthy children using a mix of PerCP-Cy5.5-labeled MAbs to confirm the reliability of CD22 as a pan-B-cell marker. Flow cytometric analyses within a BM lymphogate showed that $\mathrm{CD} 22$ is rarely expressed on $\mathrm{CD}^{+}{ }^{+} \mathrm{T}$ cells, $\mathrm{CD} 16^{+} \mathrm{NK}$ cells, or $\mathrm{CD}^{2} 3^{+}$myeloid cells, thereby confirming the reliability of $\mathrm{CD} 22$ as a pan-Bcell marker. 
A
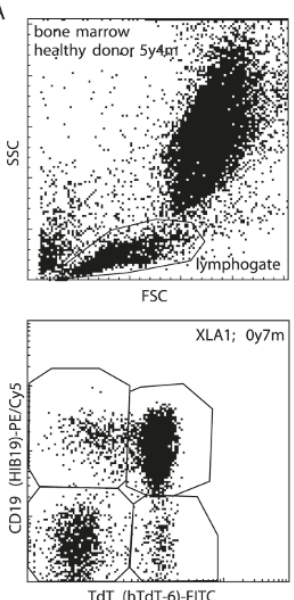

TdT (hTdT-6)-FITC

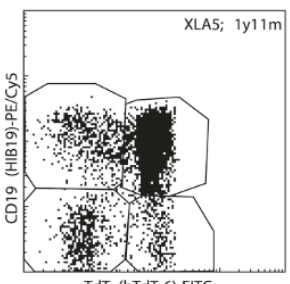

TdT (hTdT-6)-FITC

B
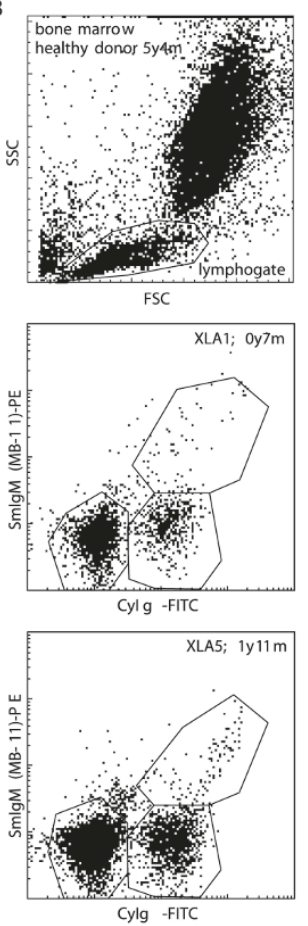

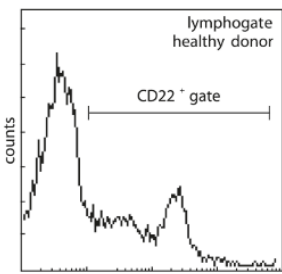

CD22 (Leu-14)-PE/Cy5
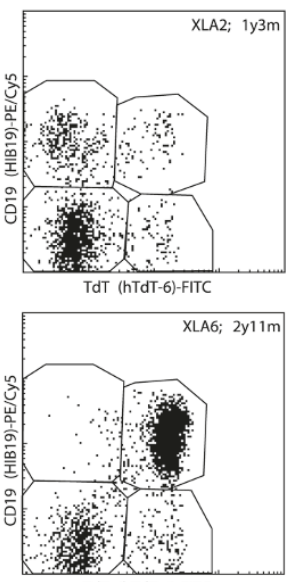

TdT (hTdT-6)-FITC
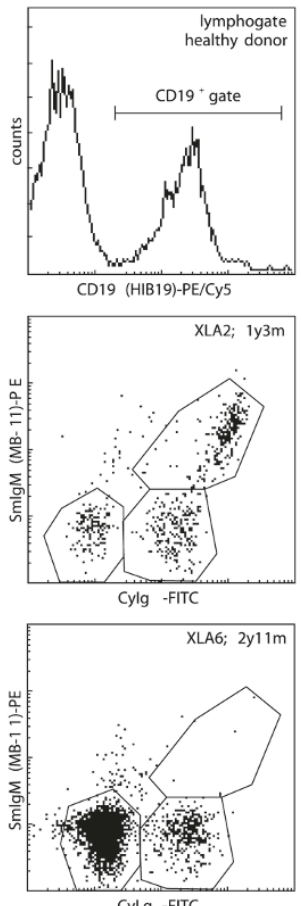
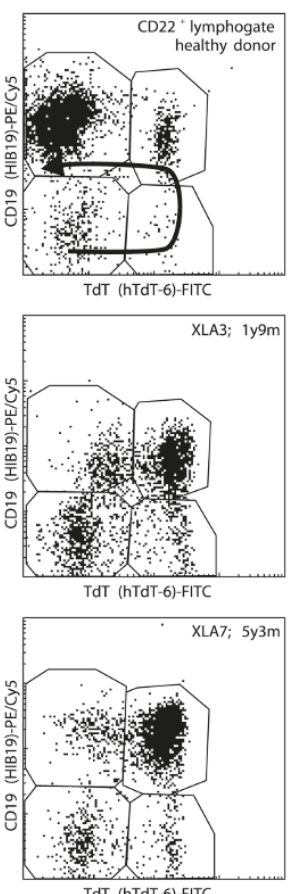

TdT (hTdT-6)-FITC
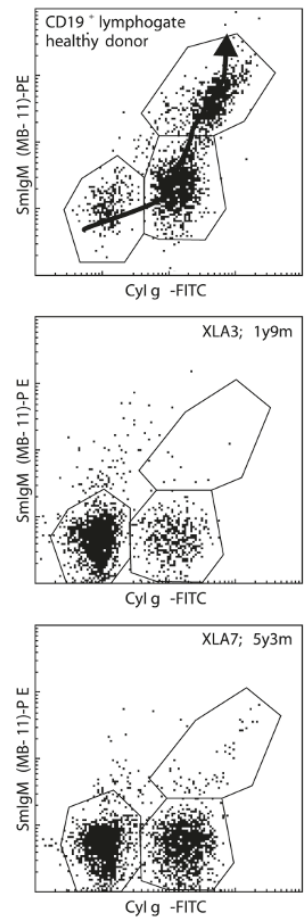

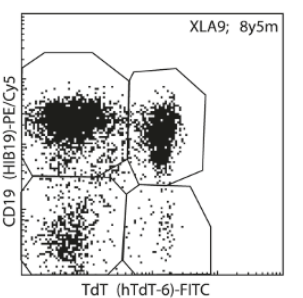

TdT (hTdT-6)-FITC

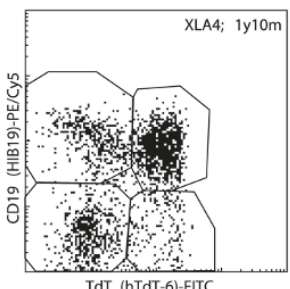

TdT (hTdT-6)-FITC
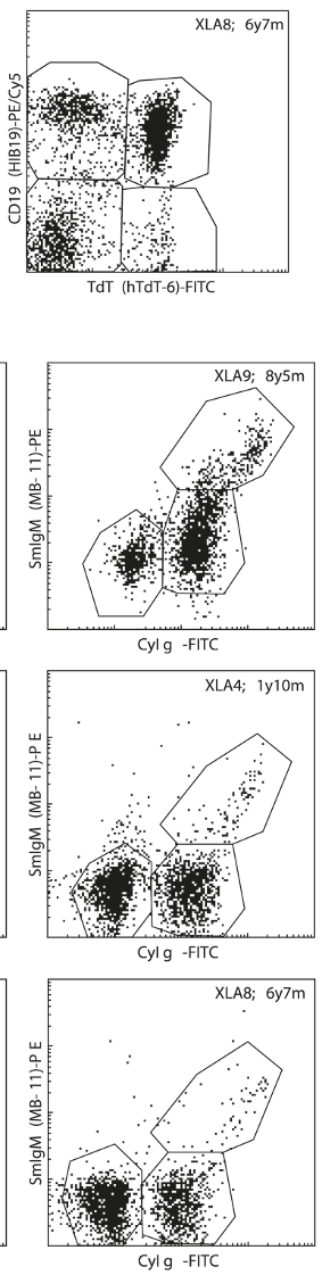

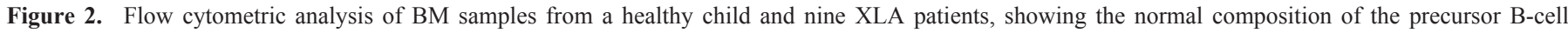

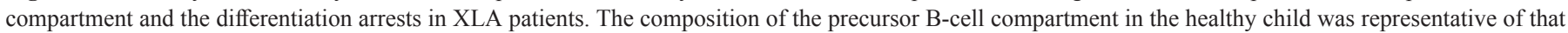

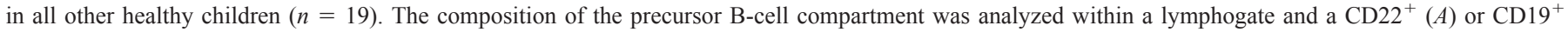

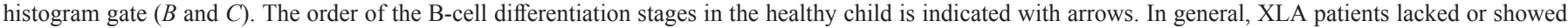
a severe reduction in the more mature B-cell differentiation stages with a relative increase in the immature B-cell differentiation stages.

the splice site sequences could be evaluated as well. All sequencing was performed as described before (32) and run on an ABI Prism 377 fluorescent sequencer (Applied Biosystems).

Isolation of PCR products from agarose gels. RT-PCR products from XLA patient 9 were separated in a $1 \%$ agarose gel stained with ethidium bromide. Under UV illumination, two bands of different sizes were cut out of the gel and frozen for $15 \mathrm{~min}$ at $-20^{\circ} \mathrm{C}$. After thawing, the PCR products were isolated from the gel fragments using ultrafree-mc Millipore columns (Millipore Corporation, Bedford, MA, U.S.A.) according to the manufacturer's instructions and used directly for fluorescent sequencing. 

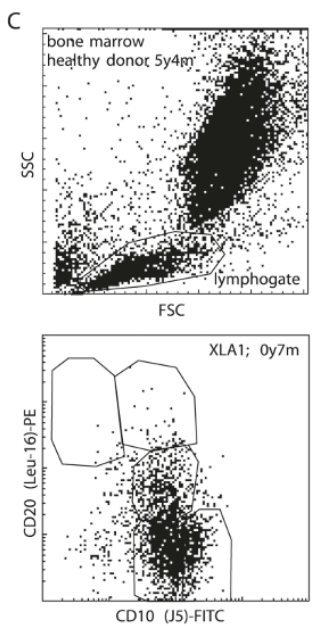

CD10 (J5)-FITC

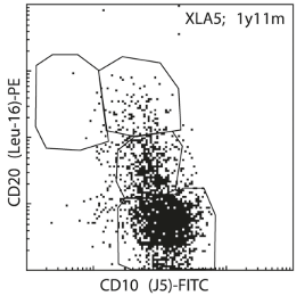

CD10 (J5)-FITC

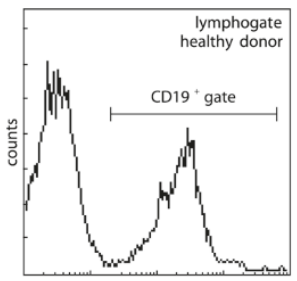

CD1 9 (HIB19)-PE/Cy5

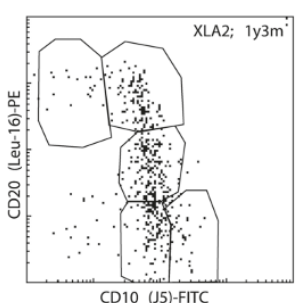

CD10 (J5)-FITC

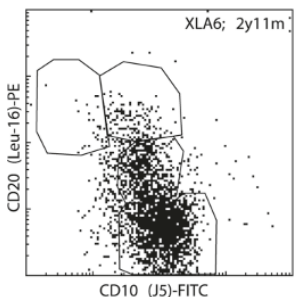

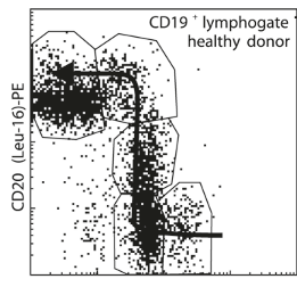

CD10 (J5)-FITC

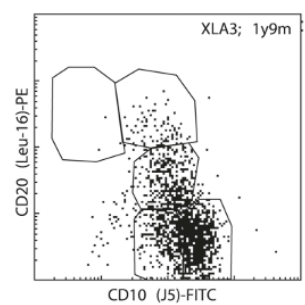

CD10 (J5)-FITC

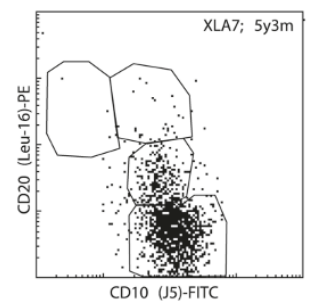

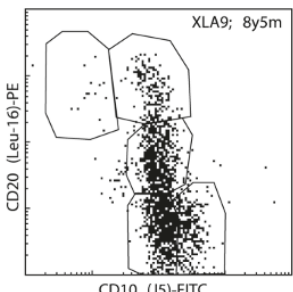

CD10 (J5)-FITC

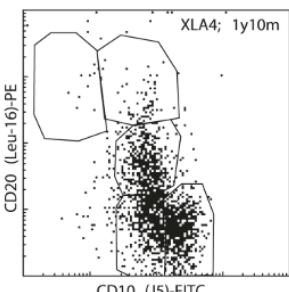

CD10 (J5)-FITC

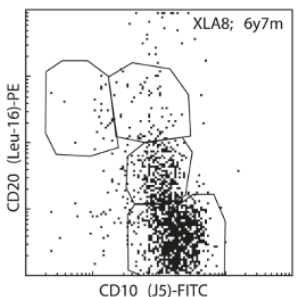

Figure 2. $C$.

\section{RESULTS}

Composition of the BM lymphogate. To characterize B-cell development in young children, BM samples from 19 healthy children and nine XLA patients were analyzed by flow cytometry, using 14 triple labelings (Table 1). The obtained percentages of $\mathrm{CD} 22^{+} \mathrm{B}$ cells in the BM lymphogate are shown in Table 2. This table illustrates the variation in composition of the lymphogate. This variation is caused by contamination of the lymphogate with T lymphocytes, NK cells, myeloid precursors, and normoblasts (Table 2). Therefore, reliable comparison of B-cell subpopulations in BM samples from healthy children and XLA patients requires analysis within a B-cell gate.

The use of CD22 as a pan-B-cell marker has been described previously $(33,34)$. To confirm the reliability of this marker we performed quadruple labelings using a mixture of PerCPCy5.5-labeled MAbs (CD3, CD33, and CD16) together with $\mathrm{CD} 22$. Analyses of BM samples from two healthy children showed that $\mathrm{CD} 22$ is rarely expressed on $\mathrm{CD}^{+} \mathrm{T}$ cells, $\mathrm{CD}^{2} 3^{+}$myeloid cells, or CD16 ${ }^{+} \mathrm{NK}$ cells (Fig. 1), thereby excluding the possibility that the $\mathrm{CD} 22^{+}$gate would include substantial numbers of non-B lineage cells. Furthermore, labelings containing both $\mathrm{CD} 22$ and $\mathrm{CD} 79$ a showed a small $\mathrm{CD} 22^{+} / \mathrm{CyCD} 79 \mathrm{a}^{-}$pro-B-cell population (data not shown). Therefore, we choose CD22 as a pan-B-cell marker instead of CyCD79a.

B-cell subsets in bone marrow from healthy donors. The markers CD22 and CD19 were used to identify the total B-cell population in $\mathrm{BM}$, because these two markers are regarded as pan-B-cell markers, which are expressed by virtually all precursor B cells. In each triple labeling, the expression pattern of the two other MAbs was analyzed within the CD22 or CD19 gate, resulting in normal differentiation pathways (Fig. 2). The apparent heterogeneity of the $\mathrm{CD} 22^{+}$gate in Figure $2 A$ was caused by different expression levels $\left(\mathrm{CD} 22^{+}\right.$and $\left.\mathrm{CD} 22^{\text {bright }}\right)$ on precursor B-cells, which was also clear from Figure 1.

Virtually all events within the B-cell gates were grouped using different regions, bringing the total percentage of identified B-cell subpopulations in each gate to approximately $100 \%$. For example, the CyIg $\mu$-SmIgM-CD19 labeling was analyzed within the CD19 gate (Fig. $2 B$ ). Three subpopulations could be distinguished (from immature to mature): $\mathrm{CyIg} \mu^{-} /$ $\mathrm{SmIgM}^{-}, \mathrm{CyIg} \mu^{+} / \mathrm{SmIgM}^{-}$, and $\mathrm{CyIg} \mu^{+} / \mathrm{SmIgM}^{+}$. An identical approach was followed for other markers within the CD22 or CD19 gates of all 14 triple labelings, resulting in the differentiation scheme in Table 3.

Several human B-cell differentiation schemes with five to six precursor B-cell subsets have been published (18-22). Pro-B, pre- $\mathrm{B}$, immature $\mathrm{B}$, and mature $\mathrm{B}$ cells were designated according to Ghia et al. (21). The $\mathrm{CD} 19^{-}$fraction was termed pro-B cells, and was further subdivided on the basis of TdT expression. Pre-B-I cells were defined as $\mathrm{CD} 19^{+}, \mathrm{CD} 10^{+}$, $\mathrm{TdT}^{+}, \mathrm{CD} 4^{+}$, and $\mathrm{CyIg} \mu^{-}$and were further subdivided on the basis of the level of CD10 expression. Pre-B-II cells were $\mathrm{CD} 19^{+}, \mathrm{CD} 10^{+}, \mathrm{TdT}^{-}, \mathrm{CD} 34^{-}$, and $\mathrm{CyIg} \mu^{+}$, and were further subdivided on the basis of the presence or absence of CD20 expression. Immature B cells were $\mathrm{CD} 19^{+}, \mathrm{CD} 10^{+}$, $\mathrm{SmIgM}^{+}$, and $\mathrm{SmIgD}^{-}$, whereas mature B cells were $\mathrm{CD} 19^{+}$, $\mathrm{CD}_{10}^{-}, \mathrm{SmIgM}^{+}$, and $\mathrm{SmIgD}^{+}$.

All percentages of precursor-B cell subpopulations in healthy children within a $\mathrm{CD} 22^{+}$or $\mathrm{CD} 19^{+}$gate are listed in the lower part of Table 3. It has been published that the relative composition of the precursor B-cell compartment is age related with several differences between children and adults (22). We 
Table 3. B-cell differentiation stages in BM from healthy children $(<16$ y)

\begin{tabular}{|c|c|c|c|c|c|c|c|c|c|}
\hline & \multirow[b]{2}{*}{ Immunologic markers } & \multirow{2}{*}{\multicolumn{2}{|c|}{ Pro-B }} & \multirow{2}{*}{\multicolumn{2}{|c|}{ Pre-B-I }} & \multicolumn{2}{|l|}{5} & 7 & \multirow{2}{*}{$\begin{array}{c}8 \\
\text { Mature B }\end{array}$} \\
\hline & & & & & & Pre-E & & Immature B & \\
\hline & CD19 & - & - & + & + & + & + & & \\
\hline & CD34 & + & + & + & + & - & - & - & - \\
\hline & TdT & - & + & + & + & - & - & - & - \\
\hline & CD10 & - & - & ++ & + & + & + & + & - \\
\hline & $\mathrm{CD} 20$ & - & - & - & - & - & + & ++ & ++ \\
\hline & CyIgM & - & - & - & - & + & + & + & + \\
\hline & SmIgM & - & - & - & - & - & - & + & + \\
\hline & SmIgD & - & - & - & - & - & - & - & + \\
\hline \multirow{2}{*}{$\begin{array}{l}\text { Mean \% within } \\
\text { CD22 gate (SD) }\end{array}$} & $<5$ y $(n=6)$ & $6.0(1.7)$ & $1.2(1.4)$ & \multicolumn{2}{|c|}{$7.6(4.0)$} & \multicolumn{4}{|c|}{$83.8(7.0)$} \\
\hline & $5-10$ y $(n=7)$ & $8.2(4.8)$ & $1.0(0.6)$ & \multicolumn{2}{|c|}{$9.1(1.5)$} & \multicolumn{4}{|c|}{$79.7(6.2)$} \\
\hline \multirow{2}{*}{$\begin{array}{l}\text { Mean \% within } \\
\text { CD19 gate (SD) }\end{array}$} & $5-10 \mathrm{y}(n=7)$ & \multicolumn{2}{|c|}{-} & $4.6(1.4)$ & $4.9(2.1)$ & $34.8(12.7)$ & $18.2(4.7)$ & $15.2(3.2)$ & $24.4(11.5)$ \\
\hline & $10-16$ y $(n=6)$ & \multicolumn{2}{|c|}{-} & $5.7(2.3)$ & $4.9(3.1)$ & $25.8(8.0)$ & $20.4(6.7)$ & $18.1(3.8)$ & $28.8(13.4)$ \\
\hline
\end{tabular}

$\mathrm{NA}=$ not analyzed. Because CD38 was not used in combination with CD22 (Table 1), no precise information about CD38 expression on pro-B cells was available. However, analysis of CD34 and CD38 expression in the lymphogate showed that $>99 \%$ of CD34 ${ }^{+}$cells were also CD38 $8^{+}$. Hao et al. $(53)$ showed that the $\mathrm{CD} 38^{-}$population comprised $3.53 \% \pm 0.68 \%$ of the $\mathrm{CD} 34^{+}$cells.

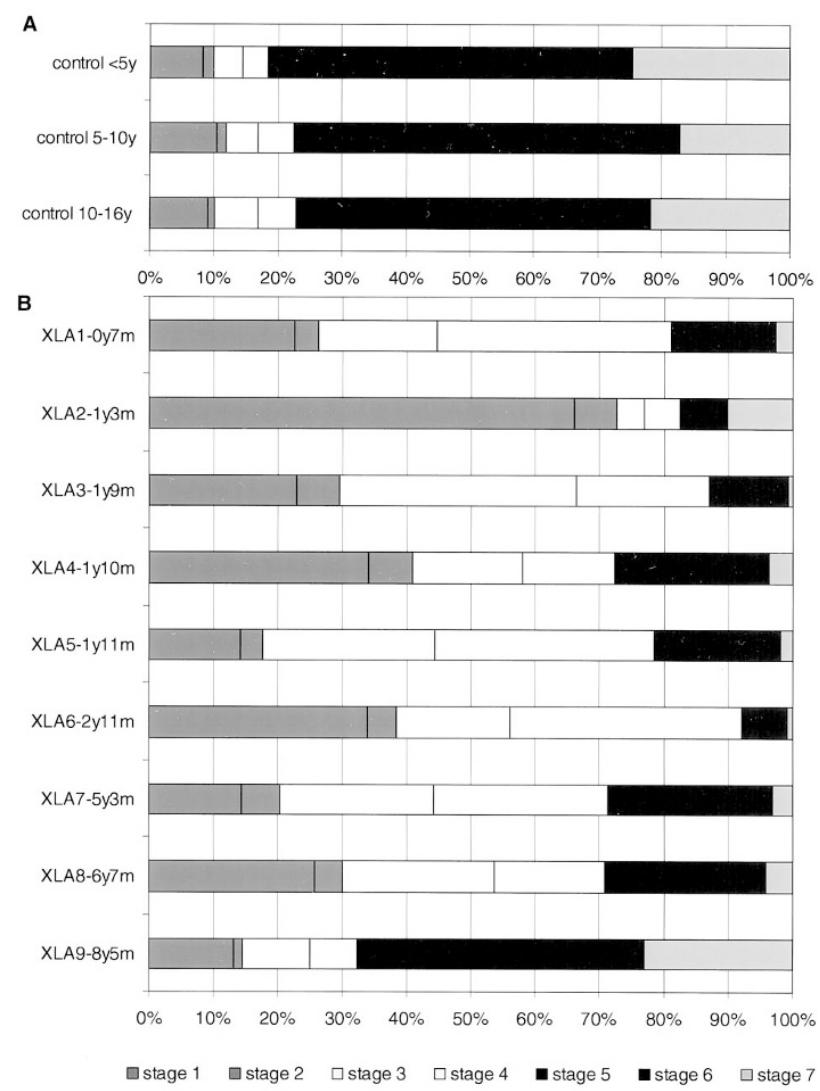

Figure 3. Composition of the precursor B-cell compartment in healthy children $(A)$ compared with XLA patients $(B)$, corrected for the composition of the lymphogate. The precursor B-cell compartment (Table 2) was set to $100 \%$. To this aim, $\mathrm{CD}^{-} 0^{-} / \mathrm{SmIgM}^{+} / \mathrm{SmIgD}^{+}$mature B cells were excluded (see text for details). Seven of nine XLA patients showed a similar differentiation arrest with approximately $80 \%$ of the precursor B cells in the pro-B and pre-B-I stages, thereby revealing an arrest at the transition from $\mathrm{CyIg} \mu^{-}$to $\mathrm{CyIg} \mu^{+}$ pre-B cells, with a variable degree of leakiness. XLA patients 2 and 9 showed different compositions of their precursor B-cell compartments. subdivided the healthy children into three age groups to check for differences among children of different age groups. Our results showed only minor nonsignificant differences in the composition of the precursor B-cell compartment in BM from children of different age groups.

Definition of $\mathrm{CD}_{22}{ }^{+}$and $\mathrm{CD}_{19^{+}} \mathrm{B}$-cell compartments. We identified the entire B-cell compartment as being $\mathrm{CD} 22^{+}$. In healthy children younger than $5 \mathrm{y}$ of age, between 5 and $10 \mathrm{y}$ of age, and between 10 and 16 y of age, the $\mathrm{CD} 19^{+}$fraction within this $\mathrm{CD} 22^{+} \mathrm{B}$-cell compartment was very large (labelings 1 and 8), i.e. $91.4 \%, 88.7 \%$, and $90.9 \%$, respectively, implying that the $\mathrm{CD} 19^{-} / \mathrm{CD} 22^{+}$pro-B-cell population was small in all three age groups (Table 3). Consequently, the percentages of the different subpopulations within the CD19 gate could be recalculated into percentages of the $\mathrm{CD} 22^{+}$ population, by multiplying with $0.914,0.887$, and 0.909 , respectively. The same approach was followed for XLA patients.

Correction of the B-cell compartment in BM for blood contamination. The mature B-cell population (stage 8) varied between healthy children mainly because of blood contamination with $\mathrm{CD}_{10}{ }^{-} / \mathrm{SmIgM}^{+} / \mathrm{SmIgD}^{+}$B-lymphocytes: $1-30 \%$ within the lymphogate (Table 2) and $8-42 \%$ within the $\mathrm{CD} 19^{+}$gate. This variable degree of blood contamination was also clear from the comparable variation of $\mathrm{CD}^{+} \mathrm{T}$ lymphocytes within the lymphogate, ranging from 9 to $35 \%$ (Table 2). To correct for this variance in our comparative studies between precursor B cells in normal BM and in BM from XLA patients, we excluded the mature $\mathrm{CD} 10^{-} / \mathrm{SmIgM}^{+} / \mathrm{SmIgD}^{+}$B-cell population from our calculations (Table 2). Consequently, the percentages of stages $1-7$ were recalculated to $100 \%$ (Fig. 3). From this recalculation, the percentages of precursor B cells in Table 2 were set to $100 \%$.

Patient characteristics and mutations in the BTK gene. The nine boys were clinically diagnosed as XLA on the basis 
Table 4. Characteristics of XLA patients

\begin{tabular}{|c|c|c|c|c|c|c|c|c|c|}
\hline \multirow[b]{2}{*}{ Patient } & \multirow[b]{2}{*}{$\begin{array}{c}\text { Age at } \\
\text { diagnosis* }\end{array}$} & \multicolumn{3}{|c|}{ Serum Ig levels at diagnosis $\dagger$} & \multirow{2}{*}{$\begin{array}{c}\text { Age at } \\
\text { BM } \\
\text { puncture }\end{array}$} & \multicolumn{2}{|c|}{ Genomic mutation $\ddagger$} & \multicolumn{2}{|c|}{ Predicted effect at protein level } \\
\hline & & $\begin{array}{l}\mathrm{IgM} \\
(\mathrm{g} / \mathrm{L})\end{array}$ & $\begin{array}{l}\operatorname{IgG} \\
(\mathrm{g} / \mathrm{L})\end{array}$ & $\begin{array}{l}\operatorname{IgA} \\
(\mathrm{g} / \mathrm{L})\end{array}$ & & Exon & Nucleotide & Amino acid & Affected domain \\
\hline XLA2 & $1 \mathrm{y} 2 \mathrm{mo}$ & 0.26 & 0.27 & 0.17 & $1 \mathrm{y} 3 \mathrm{mo}$ & 7 & 26delG & L198stop & $\mathrm{TH}$ \\
\hline XLA3 & $1 \mathrm{y} 9 \mathrm{mo}$ & $<0.1$ & 0.36 & $<0.1$ & 1 y 9 mo & 2 & 142delTC & Y40stop & $\mathrm{PH}$ \\
\hline XLA4 & $0 \mathrm{y} 7 \mathrm{mo}$ & 0.13 & 0.41 & 0.04 & $1 \mathrm{y} 10 \mathrm{mo}$ & 15 & G78A & M509I & Kinase \\
\hline XLA5 & 1 y $10 \mathrm{mo}$ & 0.13 & 0.01 & 0 & $1 \mathrm{y} 11 \mathrm{mo}$ & 15 & $\mathrm{C} 106 \mathrm{~A}$ & Y485stop & Kinase \\
\hline XLA7 & $1 \mathrm{y} 8 \mathrm{mo}$ & NA & $<0.3$ & NA & 5 y 3 mo & 14 & C98A & Y425stop & Kinase \\
\hline XLA8 & 6 y $7 \mathrm{mo}$ & $<0.1$ & 3.0 & $<0.05$ & 6 y 7 mo & 18 & $\mathrm{~T} 10 \mathrm{C}$ & M587T & Kinase \\
\hline XLA9 & 8 y 4 mo & 0.05 & 4.7 & 0.4 & 8 y 5 mo & 3 & G99A & L119stop & $\mathrm{PH}$ \\
\hline
\end{tabular}

* XLA diagnosis was based on strongly reduced or absent numbers of B lymphocytes in the PB and hypogammaglobulinemia.

$\dagger$ Lower level normal serum Ig values according to Cejka et al. (35): 5-12 mo: IgM 0.47, IgG 4.34, IgA 0.15; $1-2$ y: IgM 0.39, IgG 3.69, IgA 0.15; 2-3 y: $\operatorname{IgM} 0.53, \operatorname{IgG} 5.10, \operatorname{IgA} 0.25,6-9$ y: $\operatorname{IgM} 0.54, \operatorname{IgG} 6.83, \operatorname{IgA} 0.32$.

$\dagger$ The beginning of each exon is numbered as 1 .

$\S$ Mutation in donor splice site of exon 3 with mutant and wt BTK mRNA detectable.

$\mathrm{NA}=$ not analyzed.

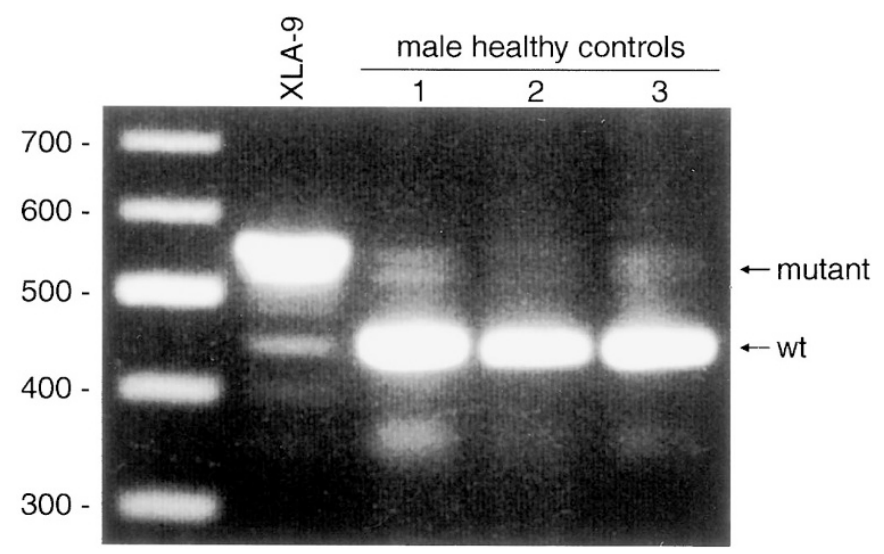

Figure 4. RT-PCR analysis of BTK mRNA from PB granulocytes of XLA patient 9 and three healthy male control children. XLA patient 9 predominantly expressed the mutated form (upper band) with 106 nucleotides inserted from intron 3. Small amounts of wt BTK mRNA (lower band) could be detected.

of hypo- or agammaglobulinemia (35) and strongly reduced or undetectable numbers of mature B lymphocytes in the PB. Analysis of PB mature B lymphocytes for SmIgM/SmIgD expression showed that XLA patients 1, 4, 5, and 7 had very low percentages $(<0.1 \%$ of lymphocytes $)$ of $\mathrm{SmIgM}^{++}$ $\mathrm{SmIgD}^{+}$B lymphocytes. In XLA patients 3 and 6 , no $\mathrm{SmIg}^{+}$ B lymphocytes could be detected. XLA patient 2 had $0.6 \%$ $\mathrm{SmIgM}^{+/++} / \mathrm{SmIgD}^{+}$B lymphocytes at the age of 6 y $5 \mathrm{mo}$, whereas XLA patient 8 had $0.3 \% \mathrm{SmIgM}^{++} / \mathrm{SmIgD}^{+} \mathrm{B}$ lymphocytes at the age of 6 y 7 mo. XLA patient 9 was diagnosed at $8 \mathrm{y}$ of age and had $1.0 \%$ of $\mathrm{SmIgM}^{+/++} / \mathrm{SmIgD}^{+} \mathrm{B}$ lymphocytes in the $\mathrm{PB}$ and almost normal levels of $\mathrm{IgG}$ and IgA, but decreased levels of IgM (Table 4).

Mutation analysis of the BTK gene was performed at the DNA level. We found five point mutations, one splice site mutation, two small deletions, and one insertion. Five mutations (XLA patients 1, 4, 5, 6, and 7) had already been observed in other patients $(5,36-41)$, whereas the other four mutations (XLA patients 2, 3, 8, and 9) were previously unknown. The entire BTK gene of each patient was sequenced to exclude additional mutations. The predicted effects of these mutations on the protein level are summarized in Table 4. Except for XLA patient 9, all BTK mutations would lead to absence of functional BTK proteins, either because of aa substitutions in the BTK kinase domain or because of premature stop codons.

In XLA patient 9, the last nucleotide of exon 3 was mutated. This mutation did not give rise to an aa substitution. However, RT-PCR analysis on mRNA from PB granulocytes generated two bands of different sizes, which were isolated and sequenced. We identified a dominant mutated form of BTK mRNA with 106 nucleotides inserted from intron 3, but also low levels of wt BTK mRNA (Fig. 4). Quantitative analysis by real-time quantitative PCR with TaqMan technology of wt $B T K$ mRNA expression in PB granulocytes of this patient indicated that $<5 \%$ of normal levels were present (data not shown).

Flow cytometric analysis of $B M$ precursor $B$ cells from XLA patients. Because of lack of BM cells, a few triple labelings could not be performed in some XLA patients. Particularly labeling 7 (SmIgD/SmIgM/CD19) could not be performed on BM samples from XLA patients 2, 3, 4, and 7. In these four XLA patients we used the $\mathrm{CD} 10^{-} / \mathrm{SmIgM}^{+}$population to identify mature B cells. In five XLA patients we used thawed BMMC because no fresh BM samples were available (see "Methods").

In $\mathrm{BM}$ from healthy children, approximately $20 \%$ of the B-cell compartment consisted of $\mathrm{CyIg} \mu^{-}$precursor B cells, equally distributed over pro-B cells and pre-B-I cells (pro-B/ pre-B-I ratio of $1.2 \pm 0.8$ ), whereas in BM from eight of nine XLA patients approximately $80 \%(71-92 \%)$ of the B-cell compartment was located in these stages (Fig. 3). Therefore, our results indicate that the differentiation arrest in the eight XLA patients resulted in a 4-fold relative accumulation of B-cell subpopulations located before the transition from $\mathrm{CyIg} \mu^{-}$to $\mathrm{CyIg} \mu^{+}$pre-B cells. The relative accumulation of $\mathrm{CyIg} \mu^{-}$precursor B cells was somewhat lower for pro-B cells $(18-42 \%)$ compared with pre-B-I cells $(34-63 \%$; Fig. 3B), resulting in a mean pro-B/pre-B-I ratio of $0.6 \pm 0.3$ in seven of the eight XLA patients. Although this differentiation arrest was 

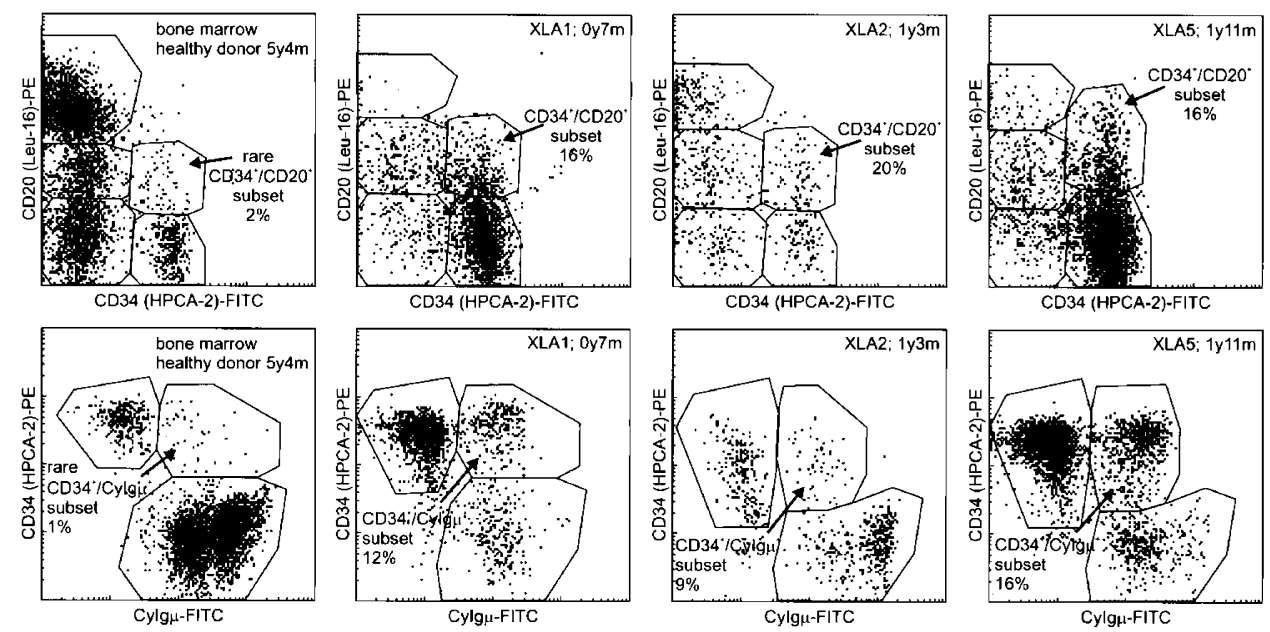

Figure 5. Flow cytometric analysis of CD34/CD20 coexpression within the CD19 ${ }^{+}$lymphogate of BM from a healthy child and three XLA patients. In all healthy children the markers CD34 and CD20 were virtually exclusive $\left(\mathrm{CD} 34^{-} / \mathrm{CD} 20^{-}\right.$population, stage 5). However, most XLA patients showed a dominant $\mathrm{CD} 34^{+} / \mathrm{CD} 20^{+}$population (upper panel). This $\mathrm{CD} 34^{+} / \mathrm{CD} 20^{+}$population originated from prolonged CD34 expression, inasmuch as in XLA patients a large proportion of $\mathrm{CyIg} \mu^{+}$pre-B-II cells was also $\mathrm{CD} 34^{+}$(lower panel). XLA patients 2 and 5 showed the smallest and largest $\mathrm{CD} 34^{+} / \mathrm{CyIg} \mu^{+}$populations, respectively. XLA patient 1 was selected as a representative example of all other XLA patients (except for XLA patient 9).

virtually identical in seven of the eight XLA patients, the percentage of B-cell subpopulations located behind the arrest $\left(\mathrm{CyIg} \mu^{+}\right.$pre-B-II cells and immature B cells) was variable, indicating leakiness (Fig. 3B).

Of the eight XLA patients with absence of functional BTK proteins, only XLA patient 2 displayed an atypical differentiation pattern with $73 \% \mathrm{CD} 19^{-} / \mathrm{CD} 22^{+}$pro-B cells and $10 \%$ pre-B-I cells (pro-B/pre-B-I ratio of 7.4). Apparently, in this patient a major differentiation arrest was located at a very early stage, i.e. at the transition from pro-B cells to $\mathrm{CyIg} \mu^{-}$pre-B-I cells (Fig. $3 B$ ). However, the $\operatorname{SmIgM}^{+}$B-cell population was extensive compared with other XLA patients, suggesting a second arrest at the transition from immature $\mathrm{SmIgM}^{+}$to mature $\mathrm{SmIgM}^{+} / \mathrm{SmIgD}^{+} \mathrm{B}$ cells.

XLA patient 9 showed an apparently normal composition of the precursor B-cell compartment. Nevertheless, this patient had diminished percentages of mature B cells in his BM (Table 2) and in his PB.

In general, seven of the eight XLA patients with absence of functional BTK proteins showed a similar differentiation arrest at the transition from $\mathrm{CyIg} \mu^{-}$to $\mathrm{CyIg} \mu^{+}$pre-B cells, with a variable degree of leakiness (Fig. $3 B$ ).

Atypical B-cell differentiation patterns in BM from $X L A$ patients. In BM samples from healthy children, coexpression of the markers CD34 and CD20 was virtually absent (Table 3), as $<4.4 \% \mathrm{CD} 4^{+} / \mathrm{CD} 20^{+}$cells were detectable (Fig. 5). However, in BM from most XLA patients a substantial $\mathrm{CD}^{+} 4^{+} /$ $\mathrm{CD} 20^{+} / \mathrm{CD} 19^{+}$population could be identified. This atypical B-cell population varied among XLA patients from 11 to $20 \%$, but was smaller $(6 \%)$ in XLA patient 9 . The atypical marker expression was predominantly caused by prolonged expression of CD34, because in BM samples from XLA patients $9-16 \%$ of $\mathrm{CyIg} \mu^{+}$pre-B-II cells was CD34 ${ }^{+}(4 \%$ in XLA patient 9), compared with $<2.4 \%$ in healthy children (Fig. 5).

\section{DISCUSSION}

We have analyzed BM samples from 19 healthy children by flow cytometry, using 14 triple labelings, revealing the normal composition of the precursor B-cell compartment (Fig. 2). This resulted in an accurate human B-cell differentiation scheme, which resembles the classification according to Ghia et al. (21). Our scheme, in which Ig expression patterns are dominant variables, consists of eight consecutive stages and is summarized in Table 3. Similar analysis of the composition of the precursor B-cell compartment in BM from nine XLA patients showed that approximately $80 \%$ (71-92\%) of the B-cell compartment in eight of these patients consisted of $\mathrm{CyIg} \mu^{-}$precursor B cells (pro-B cells and pre-B-I cells), in contrast to approximately $20 \%$ in healthy children. This is in line with the results of Campana et al. (11), who described a maturation arrest at the transition between $\mathrm{CyIg} \mu^{-}$and $\mathrm{CyIg} \mu^{+}$pre-B cells in BM of XLA patients. The localization of this arrest at the transition between $\mathrm{CyIg} \mu^{-}$and $\mathrm{CyIg} \mu^{+}$pre-B cells in seven of the eight XLA patients with absence of functional BTK proteins suggests that BTK proteins are required for the expansion of the CyIg $\mu^{+}$pre-B-II population by signaling via the pre-BCR, which is expressed on CyIg $\mu^{+}$pre-B cells (21, 42). This is supported by the finding that BTK is constitutively phosphorylated in a pre-B-cell line, which implicates a functional role for BTK in pre-BCR signaling during B-cell development (43).

B-cell differentiation arrests have been analyzed in BM samples from patients with non-X-linked causes of agammaglobulinemia. These patients have mutations in genes that encode other components of the pre-BCR, such as the $\mu$ heavy chain or $\lambda 5 / 14.1(44,45)$, or in genes that encode proteins involved in signaling via the pre-BCR, such as CD79a or B-cell linker protein (BLNK) $(46,47)$. BLNK is an adapter protein, which plays a role in the same signal-transduction 
pathway as BTK (48). The B-cell differentiation arrest in BM from these non-XLA patients seems to be comparable to the arrest in XLA patients and is also located at the transition from CyIg $\mu^{-}$pre-B-I cells to CyIg $\mu^{+}$pre-B-II cells (49). These results strongly support a role for BTK at the pre-BCR checkpoint in human B-cell development.

The flow cytometric data of the XLA patients clearly show a relative accumulation of $\mathrm{CyIg} \mu^{-}$precursor B cells, particularly of pre-B-I cells (Fig. 3B). This is in contrast with the studies by Campana et al. (11), who described normal frequencies of $\mathrm{CyIg} \mu^{-}$precursor B cells, and Pearl et al. (10), who described normal frequencies of CyIg $\mu^{+}$precursor B cells in their XLA patients. These discrepancies are probably related to differences in techniques and in age of the studied patients. Our results are in line with the study by Nomura et al. (15), who described significantly increased percentages of precursor B cells located before the blockade.

We hypothesized that accurate characterization of the B-cell differentiation arrest in BM of XLA patients would help to explain the level of immunologic variation previously reported $(10,11)$. In seven of the eight XLA patients with absence of functional BTK proteins, this differentiation arrest appeared to be very similar, with a large $\mathrm{CyIg} \mu^{-}$precursor B-cell compartment and a more prominent accumulation of pre-B-I cells compared with pro-B-cells, resulting in a pro-B/pre-B-I ratio of $0.6 \pm 0.3$, which is significantly lower (Mann-Whitney $U$ test for unrelated groups with unequal SDs; $p<0.03$ ) than in normal BM $(1.2 \pm 0.8)$. Although the arrest was similar, the degree of leakiness, indicated by the percentage of B-cell subpopulations located behind the arrest, varied among these seven XLA patients (Fig. $3 B$ ). The age of the XLA patients was comparable and the percentage of myeloid cells in the lymphogate did not differ significantly between patients, indicating that none of the patients suffered from infections at the time of $\mathrm{BM}$ donation. It seems therefore most likely that other genetic factors influence the degree of leakiness, as has also been suggested with respect to the heterogeneity of the clinical picture of XLA $(7,8)$.

In the eighth XLA patient (XLA-2), the $\mathrm{CyIg} \mu^{-}$precursor B-cell compartment mainly consisted of pro-B cells (pro-B/ pre-B-I ratio of 7.4). This particularly concerned the most immature $\mathrm{CD} 22^{+} / \mathrm{CD}_{1} 9^{-} / \mathrm{TdT}^{-}$pro-B cells (stage 1 ), which represented $66 \%$ of the total precursor B-cell compartment in this patient (Figs. $2 A$ and $3 B$ ). Curiously, the percentage of $\mathrm{SmIgM}^{+} \mathrm{B}$ cells was also increased in this patient compared with other XLA patients, indicating a second arrest at the transition from immature to mature $\mathrm{B}$ cells. We do not have an explanation for this unique composition of the precursor B-cell compartment.

It is interesting to note that the precursor B cells of XLA patient 9, which can generate low levels of wt BTK mRNA (Fig. 4), apparently can overcome the differentiation arrest at the pre-BCR level, as CyIg $\mu^{+}$pre-B-II cells were present in near normal frequencies in the BM of this patient (Fig. $3 B$ ). However, the reduced numbers of mature $B$ lymphocytes in the $\mathrm{PB}$ of this patient indicate that the differentiation arrest at the BCR level is more severe. This means that if BTK proteins are indeed involved in signaling via the pre-BCR, lower amounts of BTK are needed for signal transduction from the pre-BCR compared with the BCR. The phenotype of this patient resembles that of X-linked immunodeficiency mice, which have a point mutation in the pleckstrin homology domain or a targeted deletion of BTK. These mice show normal precursor B-cell compartments in BM, but reduced numbers of mature B lymphocytes in $\mathrm{PB}$, and predominantly lack $\operatorname{IgM}$ and $\operatorname{IgG}_{3}$ in the serum (50-52).

The marker expression on precursor B cells in BM samples from the seven similar XLA patients seemed to be normal until the pre-B-II stage, in which CyIg $\mu$ is expressed, was reached. The markers CD34 and CD20 showed virtually no coexpression in healthy children, but were coexpressed in these XLA patients, resulting in a clearly detectable $\mathrm{CD} 34^{+} / \mathrm{CD} 20^{+} /$ $\mathrm{CD} 19^{+}$population (Fig. 5). The coexpression appeared to be caused by prolonged CD34 expression, as a large proportion of $\mathrm{CyIg} \mu^{+}$pre-B-II cells was CD $34^{+}$. This suggests that normally CD34 down-regulation is mediated via pre-BCR signaling.

In conclusion, the B-cell differentiation arrest in the majority of XLA patients appeared to be homogeneous, with approximately $80 \%$ of the precursor B-cell compartment being negative for $\mathrm{CyIg} \mu$ expression. The size and nature of the residual more mature B-cell population (leakiness) varied among patients, independent of the type of BTK mutation. Furthermore, it appears that the composition of the precursor B-cell compartment in BM of some XLA patients can be influenced by low levels of wt $B T K$ mRNA, as was particularly illustrated by XLA patient 9. It would be interesting to analyze the presence of wt $B T K$ mRNA levels in other XLA patients with splice site mutations in the BTK gene. Because low levels of wt BTK mRNA appear to be sufficient for a seemingly normal composition of the precursor B-cell compartment, one might expect more mature B lymphocytes in the PB and higher serum Ig levels in these patients.

Acknowledgments. The authors thank Drs. P.M. Hoogerbrugge and J.M.J.J. Vossen, Mrs. Pijl and Mrs. Moeselaar from the Department of Pediatrics at the Leiden University Medical Center for collecting BM samples from healthy children, Dr. T. Kuijpers from the Department of Pediatrics at the Emma Children's Hospital in Amsterdam, Dr. G. Brinkhorst from the Department of Pediatrics at the Medical Center Alkmaar, and Dr. E.J.A. Gerritsen from the Department of Pediatrics at the St. Clara Hospital in Rotterdam for sending BM samples from XLA patients.

\section{REFERENCES}

1. Smith CIE, Witte ON 1999 X-linked agammaglobulinemia: a disease of BTK tyrosine kinase. In: Ochs HD, Smith CIE, Puck JM (eds) Primary immunodeficiency diseases: a molecular and genetic approach. Oxford University Press, New York, pp 263-284

2. Holinski-Feder E, Weiss M, Brandau O, Jedele KB, Nore B, Bäckesjö CM, Vihinen M, Hubbard SR, Belohradsky BH, Smith CIE, Meindl A 1998 Mutation screening of the $B T K$ gene in 56 families with X-linked agammaglobulinemia (XLA): 47 unique mutations without correlation to clinical course. J Pediatr 101:276-284

3. Vetrie D, Vorechovsky I, Sideras P, Holland J, Davies A, Flinter F, Hammarström L, Kinnon C, Levinsky R, Bobrow M, Smith CIE, Bentley DR 1993 The gene involved in X-linked agammaglobulinaemia is a member of the $\operatorname{src}$ family of protein-tyrosine kinases. Nature 361:226-233

4. Tsukada S, Saffran DC, Rawlings DJ, Parolini O, Allen RC, Klisak I, Sparkes RS, Kubagawa H, Mohandas T, Quan S, Belmont JW, Cooper MD, Conley ME, Witte ON 
1993 Deficient expression of a B cell cytoplasmic tyrosine kinase in human X-linked agammaglobulinemia. Cell 72:279-290

5. Vihinen M, Kwan SP, Lester T, Ochs HD, Resnick I, Valiaho J, Conley ME, Smith CIE 1999 Mutations of the human BTK gene coding for Bruton tyrosine kinase in Xlinked agammaglobulinemia. Hum Mutat 13:280-285

6. Gaspar HB, Lester T, Levinsky RJ, Kinnon C 1998 Bruton's tyrosine kinase expression and activity in X-linked agammaglobulinaemia (XLA): the use of protein analysis as a diagnostic indicator of XLA. Clin Exp Immunol 111:334-338

7. Bykowsky MJ, Haire RN, Ohta Y, Tang H, Sung SS, Veksler ES, Greene JM, Fu SM, Litman GW, Sullivan KE 1996 Discordant phenotype in siblings with X-linked agammaglobulinemia. Am J Hum Genet 58:477-483

8. Kornfeld SJ, Haire RN, Strong SJ, Brigino EN, Tang H, Sung S-SJ, Fu SM, Litman GW 1997 Extreme variation in X-linked agammaglobulinemia phenotype in a three-generation family. J Allergy Clin Immunol 100:702-706

9. Vogler LB, Pearl ER, Gathings WE, Lawton AR, Cooper MD 1976 B lymphocyte precursors in bone-marrow in immunoglobulin deficiency diseases. Lancet 2:376

10. Pearl ER, Vogler LB, Okos AJ, Crist WM, Lawton AR, Cooper MD 1978 B lymphocyte precursors in human bone marrow: an analysis of normal individuals and patients with antibody-deficiency states. J Immunol 120:1169-1175

11. Campana D, Farrant J, Inamdar N, Webster AD, Janossy G 1990 Phenotypic features and proliferative activity of $\mathrm{B}$ cell progenitors in $\mathrm{X}$-linked agammaglobulinemia. J Immunol 145:1675-1680

12. Gaspar HB, Ferrando M, Caragol I, Hernandez M, Bertran JM, De Gracia X, Lester T, Kinnon C, Ashton E, Espanol T 2000 Kinase mutant Btk results in atypical X-linked agammaglobulinaemia phenotype. Clin Exp Immunol 120:346-350

13. de Weers M, Dingjan GM, Brouns GS, Kraakman MEM, Mensink RGJ, Lovering RC, Schuurman RKB, Borst J, Hendriks RW 1997 Expression of Bruton's tyrosine kinase in B lymphoblastoid cell lines from X-linked agammaglobulinaemia patients. Clin Exp Immunol 107:235-240

14. Kobayashi S, Iwata T, Saito M, Iwasaki R, Matsumoto H, Naritaka S, Kono Y, Hayashi Y 1996 Mutations of the Btk gene in 12 unrelated families with X-linked agammaglobulinemia in Japan. Hum Genet 97:424-430

15. Nomura K, Kanegane H, Karasuyama H, Tsukada S, Agematsu K, Murakami G, Sakazume S, Sako M, Tanaka R, Kuniya Y, Komeno T, Ishihara S, Hayashi K, Kishimoto T, Miyawaki T 2000 Genetic defect in human X-linked agammaglobulinemia impedes a maturational evolution of pro-B cells into a later stage of pre-B cells in the B-cell differentiation pathway. Blood 96:610-617

16. Conley ME 1985 B cells in patients with X-linked agammaglobulinemia. J Immunol 134:3070-3074

17. Nonoyama S, Tsukada S, Yamadori T, Miyawaki T, Jin YZ, Watanabe C, Morio T, Yata J, Ochs HD 1998 Functional analysis of peripheral blood B cells in patients with X- linked agammaglobulinemia. J Immunol 161:3925-3929

18. Loken MR, Shah VO, Dattilio KL, Civin CI 1987 Flow cytometric analysis of human bone marrow. II. Normal B lymphocyte development. Blood 70:1316-1324

19. Ghia P, ten Boekel E, Sanz E, de la Hera A, Rolink A, Melchers F 1996 Ordering of human bone marrow B lymphocyte precursors by single-cell polymerase chain reaction analyses of the rearrangement status of the immunoglobulin $\mathrm{H}$ and $\mathrm{L}$ chain gene loci. J Exp Med 184:2217-2229

20. Dworzak MN, Fritsch G, Fleischer C, Printz D, Fröschl G, Buchinger P, Mann G, Gadner H 1997 Multiparameter phenotype mapping of normal and postchemotherapy B lymphopoiesis in pediatric bone marrow. Leukemia 11:1266-1273

21. Ghia P, ten Boekel E, Rolink AG, Melchers F 1998 B-cell development: a comparison between mouse and man. Immunol Today 19:480-485

22. Lucio P, Parreira A, van den Beemd MW, van Lochem EG, van Wering ER, Baars E, Porwit-MacDonald A, Bjorklund E, Gaipa G, Biondi A, Orfao A, Janossy G, van Dongen JJM, San Miguel JF 1999 Flow cytometric analysis of normal B cell differentiation: a frame of reference for the detection of minimal residual disease in precursor-B-ALL. Leukemia 13:419-427

23. Satterthwaite AB, Li Z, Witte ON 1998 Btk function in B cell development and response. Semin Immunol 10:309-316

24. Groeneveld K, te Marvelde JG, van den Beemd MW, Hooijkaas H, van Dongen JJ 1996 Flow cytometric detection of intracellular antigens for immunophenotyping of normal and malignant leukocytes. Leukemia 10:1383-1389

25. Van Lochem EG, Groeneveld K, Te Marvelde JG, Van den Beemd MW, Hooijkaas H, Van Dongen JJM 1997 Flow cytometric detection of intracellular antigens for immunophenotyping of normal and malignant leukocytes: testing of a new fixationpermeabilization solution. Leukemia 11:2208-2210

26. Verhagen OJHM, Wijkhuis AJM, van der Sluijs-Gelling AJ, Sczcepanski T, van der Linden-Schreven BEM, Pongers-Willemse MJ, van Wering ER, van Dongen JJM, van der Schoot CE 1999 Suitable DNA isolation method for the detection of minimal residual disease by PCR techniques. Leukemia 13:1298-1299

27. Chomczynski P, Sacchi N 1987 Single-step method of RNA isolation by acid guanidinium thiocyanate-phenol-chloroform extraction. Anal Biochem 162:156-159

28. Langerak AW, Dirks RPH, Versnel MA 1992 Splicing of the platelet-derived growth factor A-chain mRNA in human malignant mesothelioma cell lines and regulation of its expression. Eur J Biochem 208:589-596

29. van Dongen JJM, Macintyre EA, Gabert JA, Delabesse E, Rossi V, Saglio G, Gottardi E, Rambaldi A, Dotti G, Griesinger F, Parreira A, Gameiro P, Diaz MG, Malec M, Langerak AW, San Miguel JF, Biondi A 1999 Standardized RT-PCR analysis of fusion gene transcripts from chromosome aberrations in acute leukemia for detection of minimal residual disease. Report of the BIOMED-1 Concerted Action: investigation of minimal residual disease in acute leukemia. Leukemia 13:1901-1928
30. Oeltjen JC, Liu X, Lu J, Allen RC, Muzny D, Belmont JW, Gibbs RA 1995 Sixty-nine kilobases of contiguous human genomic sequence containing the alpha-galactosidase A and Bruton's tyrosine kinase loci. Mamm Genome 6:334-338

31. Pongers-Willemse MJ, Verhagen OJ, Tibbe GJ, Wijkhuijs AJ, de Haas V, Roovers E, van der Schoot CE, van Dongen JJM 1998 Real-time quantitative PCR for the detection of minimal residual disease in acute lymphoblastic leukemia using junctional region specific TaqMan probes. Leukemia 12:2006-2014

32. Szczepanski T, Pongers-Willemse MJ, Langerak AW, Harts WA, Wijkhuijs AJ, van Wering ER, van Dongen JJM 1999 Ig heavy chain gene rearrangements in T-cell acute lymphoblastic leukemia exhibit predominant DH6-19 and DH7-27 gene usage, can result in complete V-D-J rearrangements, and are rare in T-cell receptor alpha beta lineage. Blood 93:4079-4085

33. Janossy G, Coustan-Smith E, Campana D 1989 The reliability of cytoplasmic CD3 and CD22 antigen expression in the immunodiagnosis of acute leukemia: a study of 500 cases. Leukemia 3:170-181

34. Comans-Bitter WM, Versteeg S, Van Wering ER, Van der Linden-Schrever BEM, Hooijkaas H, Van Dongen JJM 1995 Surface membrane CD22 expression in precursor B-cells. In: Schlossman SF, Boumsell L, Gilks W, Harlan JM, Kishimoto T, Morimoto C, Ritz J, Shaw S, Silverstein R, Springer T, Tedder TF, Todd RF (eds) Leucocyte typing V: white cell differentiation antigens. Oxford University Press, Oxford, pp 528-530

35. Cejka J, Mood DW, Kim CS 1974 Immunoglobulin concentrations in sera of normal children: quantitation against an international reference preparation. Clin Chem 20:656-659

36. Hagemann TL, Chen Y, Rosen FS, Kwan SP 1994 Genomic organization of the Btk gene and exon scanning for mutations in patients with X-linked agammaglobulinemia. Hum Mol Genet 3:1743-1749

37. de Weers M, Mensink RGJ, Kraakman MEM, Schuurman RKB, Hendriks RW 1994 Mutation analysis of the Bruton's tyrosine kinase gene in X-linked agammaglobulinemia: identification of a mutation which affects the same codon as is altered in immunodeficient xid mice. Hum Mol Genet 3:161-166

38. Vihinen M, Vetrie D, Maniar HS, Ochs HD, Zhu Q, Vorechovsky I, Webster AD, Notarangelo LD, Nilsson L, Sowadski JM, Smith CIE 1994 Structural basis for chromosome X-linked agammaglobulinemia: a tyrosine kinase disease. Proc Natl Acad Sci USA 91:12803-12807

39. Conley ME, Rohrer J 1995 The spectrum of mutations in Btk that cause X-linked agammaglobulinemia. Clin Immunol Immunopathol 76(suppl):S192-S197

40. Jin H, Webster AD, Vihinen M, Sideras P, Vorechovsky I, Hammarstrom L, Bernatowska-Matuszkiewicz E, Smith CI, Bobrow M, Vetrie D 1995 Identification of Btk mutations in 20 unrelated patients with X-linked agammaglobulinaemia (XLA). Hum Mol Genet 4:693-700

41. Gaspar HB, Bradley LA, Katz F, Lovering RC, Roifman CM, Morgan G, Levinsky RJ, Kinnon C 1995 Mutation analysis in Bruton's tyrosine kinase, the X-linked agammaglobulinaemia gene, including identification of an insertional hotspot. Hum Mol Genet 4:755-757

42. Tsuganezawa K, Kiyokawa N, Matsuo Y, Kitamura F, Toyama-Sorimachi N, Kuida K, Fujimoto J, Karasuyama H 1998 Flow cytometric diagnosis of the cell lineage and developmental stage of acute lymphoblastic leukemia by novel monoclonal antibodies specific to human pre-B-cell receptor. Blood 92:4317-4324

43. Aoki Y, Isselbacher KJ, Pillai S 1994 Bruton tyrosine kinase is tyrosine phosphorylated and activated in pre-B lymphocytes and receptor-ligated B cells. Proc Natl Acad Sci USA 91:10606-10609

44. Yel L, Minegishi Y, Coustan-Smith E, Buckley RH, Trübel H, Pachman LM, Kitchingman GR, Campana D, Rohrer J, Conley ME 1996 Mutations in the mu heavy-chain gene in patients with agammaglobulinemia. N Engl J Med 335:1486-1493

45. Minegishi Y, Coustan-Smith E, Wang Y-H, Cooper MD, Campana D, Conley ME 1998 Mutations in the human $\lambda 5 / 14.1$ gene result in B cell deficiency and agammaglobulinemia. J Exp Med 187:71-77

46. Minegishi Y, Coustan-Smith E, Rapalus L, Ersoy F, Campana D, Conley ME 1999 Mutations in $\operatorname{Ig} \alpha(\mathrm{CD} 79 \mathrm{a})$ result in a complete block in B-cell development. J Clin Invest 104:1115-1121

47. Minegishi Y, Rohrer J, Coustan-Smith E, Lederman HM, Pappu R, Campana D, Chan AC, Conley ME 1999 An essential role for BLNK in human B cell development. Science 286:1954-1957

48. Kurosaki T, Tsukada S 2000 BLNK: connecting Syk and Btk to calcium signals. Immunity $12: 1-5$

49. Gaspar HB, Conley ME 2000 Early B cell defects. Clin Exp Immunol 119: 383-389

50. Scher I 1982 The CBA/N mouse strain: an experimental model illustrating the influence of the X-chromosome on immunity. Adv Immunol 33:1-71

51. Khan WN, Alt FW, Gerstein RM, Malynn BA, Larsson I, Rathbun G, Davidson L, Müller S, Kantor AB, Herzenberg LA, Rosen FS, Sideras P 1995 Defective $\mathrm{B}$ cell development and function in Btk-deficient mice. Immunity 3: 283-299

52. Hendriks RW, de Bruijn MF, Maas A, Dingjan GM, Karis A, Grosveld F 1996 Inactivation of Btk by insertion of lac $Z$ reveals defects in $\mathrm{B}$ cell development only past the pre-B cell stage. EMBO J 15:4862-4872

53. Hao QL, Smogorzewska EM, Barsky LW, Crooks GM 1998 In vitro identification of single $\mathrm{CD} 34^{+} \mathrm{CD} 38^{-}$cells with both lymphoid and myeloid potential. Blood 91:4145-4151 